\title{
Visual Image of Architectural Elements in Kampung Al Munawar Palembang
}

\author{
Agus S Sadana $^{1}$, Ashri Prawesthi $\mathbf{D}^{1}$ \\ ${ }^{1}$ Department of Architecture/Faculty of Engineering, Universitas Pancasila, Indonesia \\ agussadana@gmail.com
}

\begin{abstract}
Kampung Al Munawar is a tourist village located in Palembang city. This place is interesting because it is situated on the Musi river banks and has an excellent layout form. There is an interesting term in naming the place in this village, and there are land and sea area. Land area is part of the village tends towards the land, sea area is part of the village located on the Musi big river banks. In this village, some unique elements are found by visitors' sight and remembered in their minds, in a form known as a mental map or mental image. This research combines descriptive, graphical, and quantitative analysis methods to describe a mental map or mental image recorded in an observer's mind. The results of the mental image show the unique gradation of places and objects remembered by visitors. The result shows that the land entrance area and river pier area are remembered only by $86 \%$ of observers. The row of houses leading to the sea is remembered by $93 \%$ of observers. All observers remember the row of houses and open space in the center of the village; this means that the core area attracts more visitors than its entrance and riverbanks area. However, Kampung Al Munawar can be a more interesting place if it is reached from the riverside. Therefore need to develop more activities in the riverbank area and increase the pier aesthetics to attract visitors through the river and make the seaside more meaningful.
\end{abstract}

(c) 2018 IJBESR. All rights reserved.

Keywords: visual, image, architecture, elements

\section{Introduction}

Kampung Al Munawar is an interesting place in Palembang. Kampung Al Munawar is an Arab settlement in Palembang City. It was built by Abdurrahman Al-Munawar, who came from Hadramaut, South Yemen, in the early 18th century [1]. At present, Al Munawar has developed as a tourist village, which offers the architecture uniqueness as its main fascination. This place is located in the area of $13 \mathrm{Ulu}$, Seberang Ulu, Palembang city.

As a tourist village with architecture as its main fascination, the architectural elements are the factors that determine the activeness of Kampung Al Munawar for visitors. The architectural face is an element that can be felt through the visitor's vision.

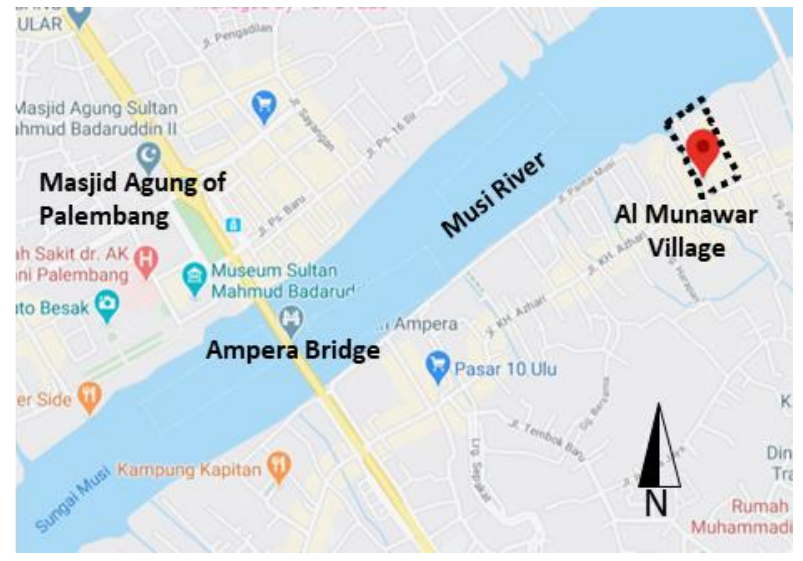

Source: (Google Maps, 2020)

Figure 1: Location of Kampung Al Munawar

Visually, the architectural elements in Kampung Al Munawar are the building's combination and its spatial environment. As the main fascination, architectural elements are 
the main thing that is perceived by the visitor's vision. Therefore, it is necessary to explore which architectural elements that make Kampung Al Munawar an attractive place.

Considering the situation, it is necessary to trace what elements are interesting, easily perceived in visitors' sight, and remembered in their minds, including the degree of performance in the respondent's memory. Thus it can be seen that the combination of forms and spatial characteristics is a situation that attracts visitors' minds.

The underlying city form elements introduced by Lynch [2] can be developed into research factors to identify the visitor's memory of a specific area. The visitor's memory level can be explored through a mental map or cognitive $\operatorname{map}[3]$.

\subsection{Visual Identity of The Place}

In the architectural or spatial environment, there is a concept of imageability and legibility. Imageability is the ability of a physical object's quality to generate a strong image for every observer. Legibility is a condition of how the observers easily navigate and move somewhere at the area by guidance from the physical elements [2,3]. Lynch [2] introduced five visually easily remembered elements as the marker and identity of a place. The elements include landmarks, paths, nodes, edges, and districts [2]. Related to the place's identity, explained that districts have a strong visual identity and an endowment of a visible boundary, active center of special characters, visible and audible landmarks at strategic points [4].

\subsection{Cognitive Map and People Perception}

Lynch [2] introduced a mental map as an image representing how people shape their perception, understand, and perceive their surroundings [5,6,7]. Referring to Lynch elements [2], a mental map is an image that represents how people shape their perception, understand, and perceive their surroundings. The elements of a mental map include (1) landmarks, (2) paths, (3) nodes, (4) edges, and (5) districts, which are useful to help visitors to navigate in an environment.

When visiting new places, people usually look for signs to help orient themselves to the environment. Landmarks are defined as an external point of reference that helps to orient both in a familiar or an unfamiliar environment [7]. Mental or cognitive maps are built from a person's perception of the environment they see. A mental image is a frame that is built to visualize and assimilate information that's also known as a cognitive map [5,6,7]. A cognitive map is related to something that represents how people perceive their surroundings, shape their perception, understand, and record it in their memory.

The previous study [6,7] shows that Lynch's elements [2]: landmarks, paths, nodes, edges, and districts are the elements that influence people's perception of place, and it works in a different environment setting an atmosphere. About the place, Trancik [9] stated that spaces would become a place when it is given a contextual meaning derived from cultural or regional content.

\subsection{Al Munawars's Architectural Elements}

The real condition shows Al Munawar is an interesting settlement that is now also becoming a cultural tourism location in Palembang city. This place is located in the ulu area of Palembang city, on the banks of the Musi River. Visually, the identities of the spatial elements in Kampung Al Munawar represent the period of its development. It is a family settlement that has a unique spatial layout and building forms, and unique names of houses. Spatially, areas directly related to the land are called land areas, while areas that 
are in direct contact with the river water body are sea areas. Palembang residents call the land area as area darat and sea area as area laut.

Referring to the facade's shape, the houses in Kampung Al Munawar represent the characteristics of the Palembang people's traditional settlements combined with European styles. This characteristic is a physical factor in describing the history of Palembang city. In Indonesian and Palembang language, the house is called rumah. There are seven unique houses names in Kampung $\mathrm{Al}$ Munawar, i.e. (1) Rumah Darat, (2) Rumah Batu, (3) Rumah Kaca, (4) Rumah Tinggi, (5) Rumah Kembar Darat, (6) Rumah Kembar Laut, and (7) Rumah Indis. Some other objects that are not too exposed are houses facing the river, houses along the corridor, and mosques.

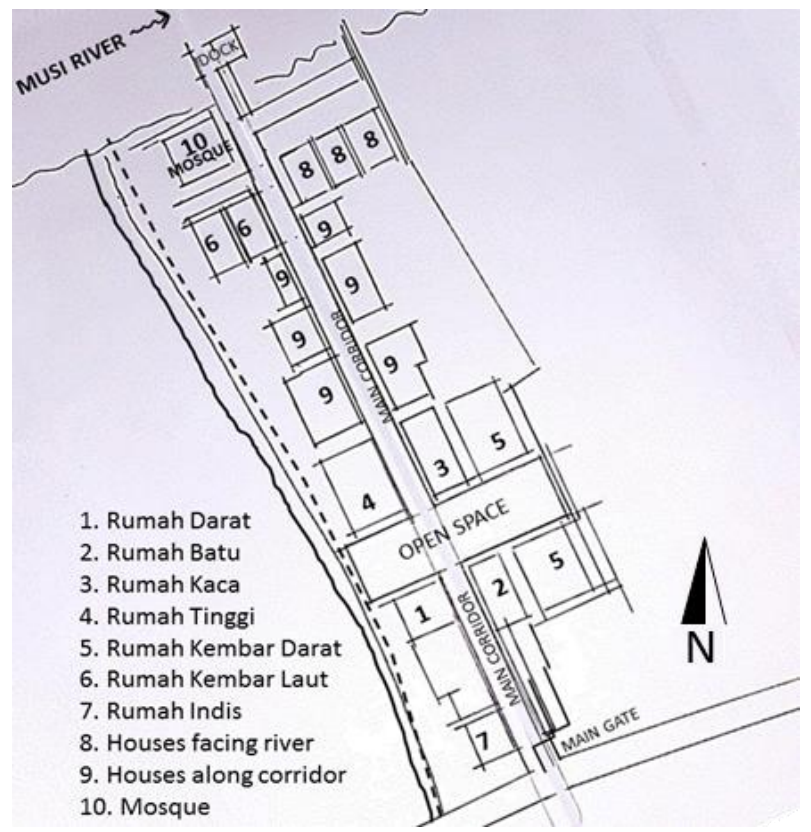

Source: (Data collection, 2019)

Figure 2: The Kampung Al Munawar, Palembang

In terms of spatial layout, Kampung $\mathrm{Al}$ Munawar has a clear main corridor and a wide-open space in the center of the village. Al Munawar has two entrances, one from the land, and the other on the river bank. The shape and placement of houses in this area provide a spatial experience that can influence the observer's perception. The attractiveness of these elements is believed to be can attract the visitors' attention. Therefore this research becomes interesting to explore the local potential of space and understand the strength of these elements in the minds of visitors.

\section{Material and Methods}

Looking at previous research [6,7], this study combines three methods: descriptive method, graphical method, and quantitative analysis to describe cognitive map recorded in the observer's mind.

The performance of architectural elements in Kampung $\mathrm{Al}$ Munawar is measured quantitatively. To find out the respondent's memory, they are transferred the elements to the map sketch on a piece of paper. The elements depicted in the sketch of each respondent are recorded and counted and tabulated into an excel table. The data collected in the table can be used to determine the element's memory level in the observer's mind. The elements memory level is measured by the percentage of one element to another. Respondents in this study are called observers.

To get data, the researcher asks the observer to describes their memories into a sketch on a piece of paper. The drawn sketches are called a cognitive map or mental map. These cognitive maps are then processed quantitatively dan compiled into a one map called map of variables. The combination of descriptive, graphic, and the quantitative calculations supports researchers to understanding the power of architectural elements to mark places and give identity of place.

Referring to the Purwanto and Darmawan's work steps [3] to over-lay the sketch made by the observers. Mental map sketches collected from observers of 14 Architecture students 
who are collecting their own research data at same location. The information presented in the map sketch was combined quantitatively tabulated into a table of architectural objects' gradation for analysis.

Table 1: Gradartion of architectural objects in Kampung Al Munawar

\begin{tabular}{|c|c|c|c|}
\hline $\begin{array}{c}\text { Degree of } \\
\text { Marked } \\
(\%)\end{array}$ & \multicolumn{2}{|c|}{ Name / Type of Objects } & $\begin{array}{l}\text { Type of } \\
\text { Elements }\end{array}$ \\
\hline 100 & \multicolumn{2}{|l|}{ Main open space } & $\begin{array}{l}\text { Landmark/ } \\
\text { Nodes }\end{array}$ \\
\hline 100 & \multicolumn{2}{|l|}{ Mosque } & $2^{\text {nd }}$ Landmark \\
\hline 100 & \multicolumn{2}{|l|}{ Main corridor } & Path \\
\hline 86 & \multicolumn{2}{|c|}{ Entrance from the land } & Nodes \\
\hline 86 & \multicolumn{2}{|c|}{ Dock / entrance fron the river } & Nodes \\
\hline 100 & \multicolumn{2}{|c|}{ Musi river } & \multirow{4}{*}{ Edges } \\
\hline 100 & \multicolumn{2}{|l|}{ Main road } & \\
\hline 50 & \multicolumn{2}{|l|}{ Watercourse } & \\
\hline 50 & \multicolumn{2}{|l|}{ Side boundary wall } & \\
\hline & \multicolumn{2}{|l|}{ Row of houses: } & \multirow{6}{*}{$\begin{array}{l}\text { Districts / } \\
\text { Landmark }\end{array}$} \\
\hline 100 & - Rumah Darat & \multirow{5}{*}{$\begin{array}{l}\text { Surroundin } \\
\mathrm{g} \text { and unity } \\
\text { with open } \\
\text { space }\end{array}$} & \\
\hline 100 & - Rumah Batu & & \\
\hline 100 & - Rumah Tinggi & & \\
\hline 100 & - Rumah Kaca & & \\
\hline 100 & $\begin{array}{l}\text { - Rumah Kembar } \\
\text { Darat }\end{array}$ & & \\
\hline 100 & \multicolumn{2}{|c|}{ - Houses along main corridor } & \multirow{5}{*}{ Districts } \\
\hline 93 & \multicolumn{2}{|c|}{ - Rumah Kembar Laut } & \\
\hline 93 & \multicolumn{2}{|c|}{ - Other houses facing river } & \\
\hline 0 & \multicolumn{2}{|c|}{ - Other landed houses } & \\
\hline 0 & \multicolumn{2}{|c|}{ - Rumah Indis (located outside) } & \\
\hline
\end{tabular}

Source: (Data collection, 2019)

Through this method, the objects described by observers are reviewed as independent variables. This means that each cognitive map does not depend on the other [7]. This research aims to determine the level of spatial cognition ability of observers to remember objects that they saw at the research location. Furthermore, the objects drawn in the maps are quantitatively calculated by their observed level.

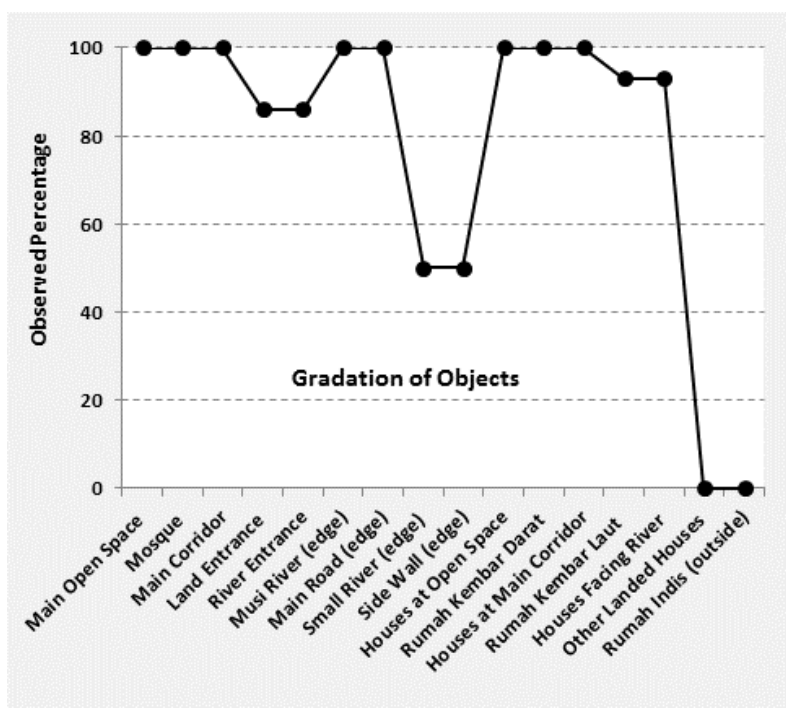

Source: (Data collection, 2019)

Figure 3: The Architectral Objects Gradation

This table is then developed into graphical form to make it easier to understand the degree of the observed object level. These objects' recording level are then transferred and summarized into the maps of variables. Through this process, the research objects are developed into variables that representing Lynch elements [2].

\section{Results and Discussions}

When people entering the Kampung Al Munawar, the quickly seen element is the open space, and then the people's housing in around the open space. These objects are placed in the village center and easy to remember by all of the observers - this open space is surrounded by a row of houses and looks like a node. Therefore visitors can use this place as the primary place marker. This means that this node also functions as a village landmark.

This place has the main corridor that was crossing open space in the center of the village. This corridor directly connects the core area with the village entrance from the land and the river. 


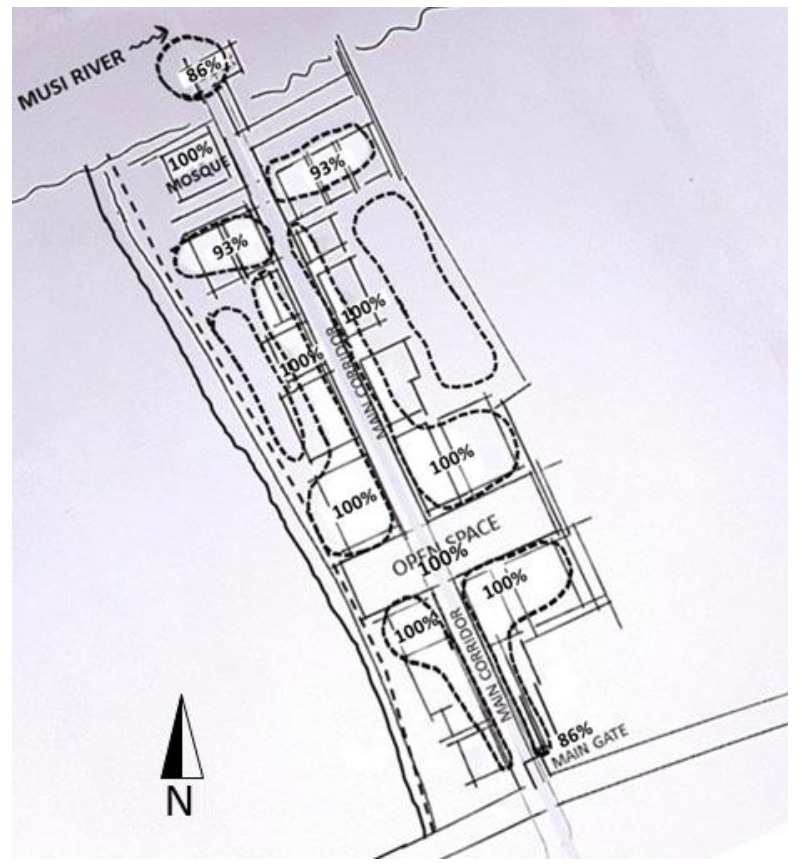

Source: (Superimpose of respondents' maps, 2019)

Figure 4: The Al Munawar's Map of Variables

There is a row of houses on the left and right of the corridor. The observer can not mention the names and number of houses on either side of this corridor, but $100 \%$ of them could remember it.

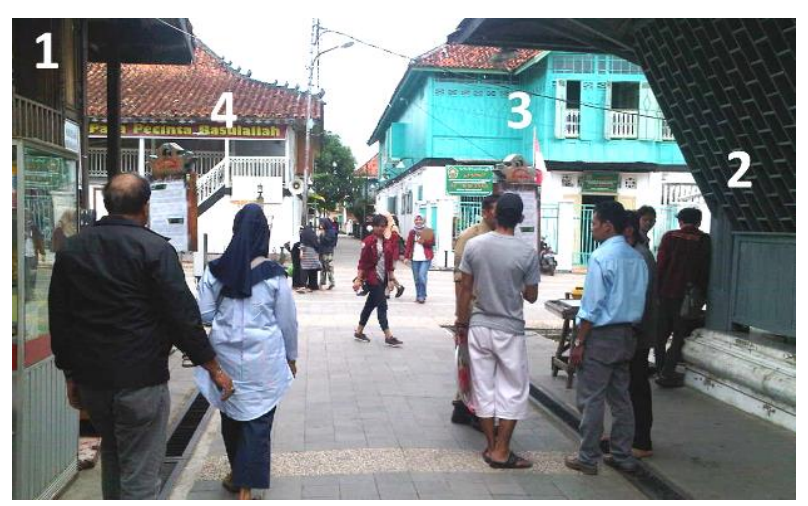

Source: (Data collection, 2019)

Figure 5: Main Corridor and Open Space of Kampung Al Munawar

It means visitors can use this corridor as guidance to navigate their movement at the $\mathrm{Al}$ Munawars' space. Six units of houses with unique names are located around the open space. These houses stand in the surrounding of open space, so the facade becomes an open space wall. These houses are remembered by $100 \%$ observers and reinforced by open space which is also felt by $100 \%$ observers. The unity of buildings with its open space makes them a very strong unit functioned as a landmark. The power of these units in influencing the observer's perception makes it as a major landmark of Kampung Al Munawar.

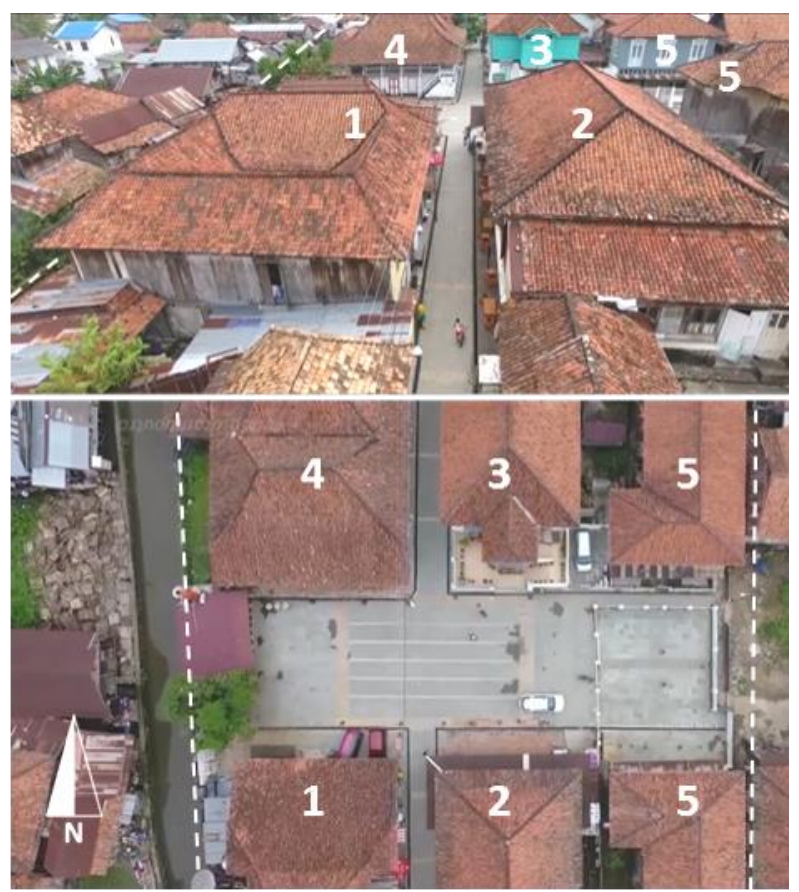

Source: (Putra [12]: Youtube.com, 2018)

Figure 6: Row of Houses Around the Open Space

The houses behind the first row are not depicted in the map sketch. It means there are no observers who remember it. Physically those houses are not directly visible from the main corridor. Those houses are located in the secondary corridors which are protected by the first-row houses yard. These conditions are actually good, that is considering Kampung Al Munawar is a livable settlement and the residents also need privacy from tourist visits. The two twin houses called Rumah Kembar Laut and rows of houses at the waterfront area are strongly felt by observers, but not all observers describe it on their cognitive map. 
Only $93 \%$ of them described it on their mental maps.

That is might be because of the current situation the banks of rivers area tend to be hidden from the land. At present waterfront area is no longer functions used as the main entrance of Kampung Al Munawar. Whereas a long time ago, the waterfront area was a village entrance. Concerning the interests of historical, cultural tourism, the waterfront area is back to be an important place to produce the village's authentic atmosphere.

As an Islamic settlement, Al Munawar has one mosque right on the river's edge. There is a pier as the entrance from the riverside side closed the mosque. In the past time, it's a village's main entrance, and the mosque is the first seen object by people before entering the core of the village. The mosque was remembered by $100 \%$ of observers, but the pier next to the mosque was felt by only $86 \%$ of observers.

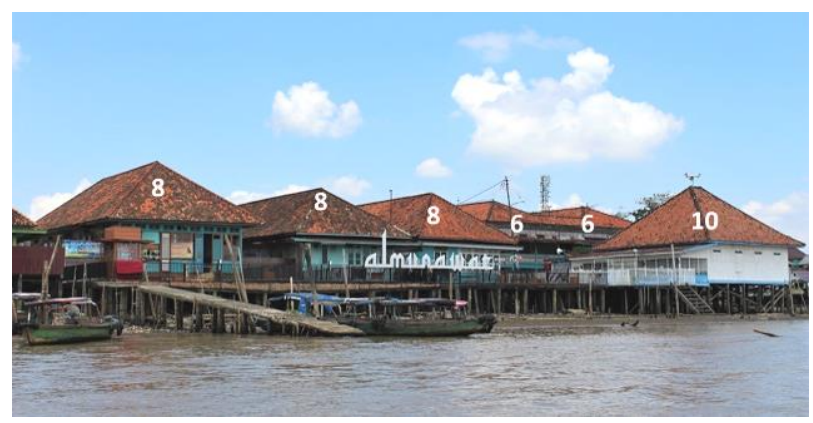

Source: (Dan On The Road [13], 2018)

Figure 7: Waterfront Area of Kampung Al Munawar

This is presumably because the people have switched to using land routes. As a result, the waterfront area around the mosque becomes somewhat hidden at the edge of the village. This observability combination illustrates the mosque as a marker of its area. It means the mosque is an important element functioned as a secondary landmark of Kampung Al Munawar, especially for the waterfront area. There are three locations where people gather, that are the open space, the land entrance, and the river entrance. From these three points, only the open space remembered by $100 \%$ observers. These open spaces functioned as a node and also a landmark. Meanwhile, the entrance both from the land or river felt only by $86 \%$ of observers. This situation illustrates the strong role of the main corridor in inviting people to go to the village center quickly.

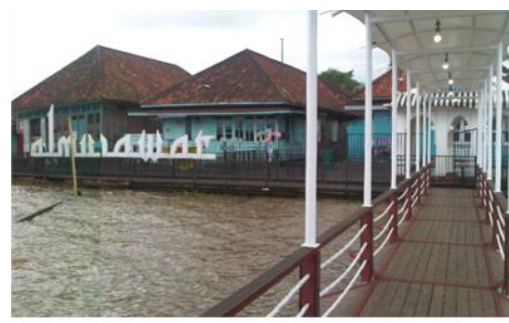

River Side Entrance - Water Front Area

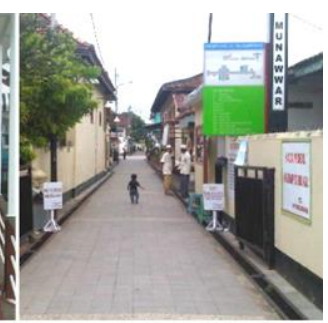

Land Side Entrance
Source: (Data collection, 2019)

Figure 8: Entrance of Kampug Al Munawar

The data collection shows that the main corridor is remembered by $100 \%$ observers. This situation shows the strength of the main corridor as the path of the village, and the village entrance is only nodes for people just to stop for a while. This ensures the function of the path as a guiding element.

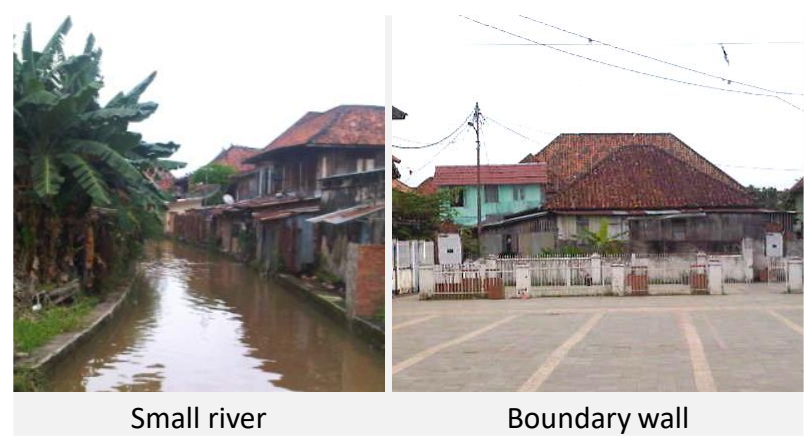

Source: (Data collection, 2019)

Figure 9: Side boundaries of Kampung Al Munawar

The Musi river, main road, watercourse to the west, and boundary walls to the east are the Kampung Al Munawar's edges. The riverside and roadside are the village's edges that also functioned as entrance points. Watercourse and boundary walls separate this area from the 
surrounding settlements. Musi river and main road remembered by $100 \%$ observers, whereas watercourse and village boundary walls can only be felt by $50 \%$ of observers. It means that the edges at the entrance side are clear and easy to find. As for the village boundary with the surrounding settlement is blurred boundaries. The combination of the river and road as the clear edges and lack dominance of the entrance gate can be interpreted in the past. The Kampung Al Munawar was a settlement that was preferred for its inhabitants. Blurred boundaries between Kampung Al Munawar with surroundings indicate that this village is an integral part of the overall region.

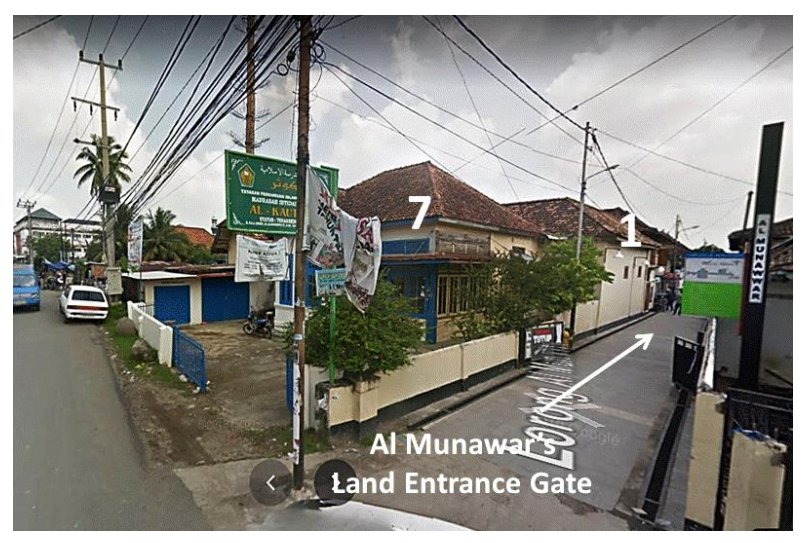

Source: (Google Maps, 2020)

Figure 10: Location of KAmpung Al Munawar

One building unit with a unique name called Rumah Indis was not observed. None of the observers described it in the map sketch even though this object located in the entrance area. There is a possibility of the object position next to the land entrance gate caused the people immediately entering the village, and not to pay attention. This condition illustrates two things, the strength of the core area magnetism and obstruction of a field of view towards objects from the main corridor settlement that preferred for its inhabitants. Blurred boundaries between Kampung Al Munawar with surroundings indicate that this village is an integral part of the overall region.

\section{Conclusion}

Referring to the data compilation presented in the mental map, it can be seen that the performance variation of Kampung Al Munawar architectural elements starting the most to the least. This element's performance variation is useful for people in understanding the place and guiding them to find, visiting, and enjoying the authentic life of the old Palembang atmosphere.

The open space in the center of the village is the first element that attracts people to go there. The unity of the open space with a row of houses surrounding it makes the place as the main node and a strong village landmark.

Main corridors with a row of houses on both sides bound by open space are effective systems for controlling the village center's human movement.

Blurred gates supported by strong open space illustrate that the open space specifically functioned as a kind of shared family space in the past.

The lack of dominance of the entrance gate, which seemed like a hidden door, illustrates that the Kampung Al Munawar was a preferred settlement for its inhabitants in the past.

The entrance gates that are less dominant but attached to a strong corridor are a good element to inviting the visitor immediately to entering the village core.

The Waterfront area is a place that is no less important. In the past, it was the entrance and front yard of the village. The presence of mosques in this area has an important role in maintaining the waterfront's existence, which is now a back area. Therefore the mosque can be classified as a secondary landmark for the village. 
The row of houses located in the center of the village and along the main corridor reinforces the village space path. On the other hand, the houses at the entrance area are not strong enough, so they seem to act as a good protector for the district's edges.

Strong edges on the arrival side indicate that this area is an easily accessible place and the whole region's different. Blurred boundaries between this village and the next settlements show Al Munawar's unity with the surrounding environment.

The row of houses located in the secondary corridors that the observer is not remembered is a good situation to protect the residents' privacy from tourist visits.

One building unit with a unique name located next to the land entrance gate becomes an unknown object, even though it is part of the village. Therefore, it's necessary to reset the object's entry point so that it can be a stronger marker for the entrance gate of Kampung Al Munawar from the land.

Finally, it can be said that the strongest element in Kampung Al Munawar is the open space at the center of the village. This node is reinforced by a row of houses surrounding and a corridor walled by a row of houses. As a result, open space is a node as well as a major landmark for this village. These elements build a strong meaning of place so that it affects the perceptions of people who come. These elements also automatically function as guidance of directions and placemarks. Kampung Al Munawar's special thing is that the houses' facades are still original as, like in the past, conditions of settlements form in Palembang city.

The architectural element power supports Kampung Al Munawar's existence towards the community situation change from the past to the present. The strength of these elements is the capital that can be developed to enhance Kampung Al Munawar's attractiveness as a tourist village to encourage people to come.

Referring to the gradation of these elements' performance, priority areas for an arrangement can be determined in accordance with the dynamics of changing situations and areas that are maintained as they are.

The goal is that visitors can feel the old Palembang settlement atmosphere, but without destroying the resident's original life. These combinations make Kampung Al Munawar become a meaningful place in the city of Palembang.

\section{Acknowledgement}

This paper is written from simple research. Primary data are collected in 2019 from the sketches of cognitive maps, which are drawn by the observers. The observers are the small group of architecture students who took their own research at the same place.

This research has limitations, which only focuses on the performance of the architecture elements when the data is collected and is not intended to compare with the performance of these elements in the past.

\section{References}

[1] Mardeli. Budaya Islam Lokal di Kampung AlMunawar Palembang. Intizar, Journal of Universitas Islam Negeri Raden Fatah Palembang; 2, 23: 271- 285.

[2] K. Lynch, The Image of the City. Cambridge: The M.I.T. Press, 1960.

[3] E. Purwanto, and E. Dharmawan, "Understanding image of the city based on spatial cognition of the observers case study: center of Semarang city," Tata Loka, vol. 15, no. 4, pp. 248-261, Nov 2013; Available online at https://ejournal2.undip.ac.id/index.php/tataloka /article/download/280/197.

[4] A. Catalani., et.al. Cities' Identity Through Architecture and Arts. London: Routledge; 2018. p 241.

[5] Bonnici T S and J McGee. Cognitive Map. Wiley Encyclopedia of Management, ed S C L Cooper, John Wiley \& Sons, 2014. 

p-issn: 2581-1347 | e-issn: 2580-2607 | Pg. 147 - 156

[6] A. S. Sadana, A. Prawesthi, and C. Puspitasari. Visual Image Of Physical Traditional Elements As An Identity Of Local Architecture In Penglipuran Village Bali. 4th Biennale ICIAP Design and Planning in the Disruptive Era, Yogyakarta. Universitas Gadjah Mada; 2018, p. 702-707; Available online at http://ugm.id/ ProsidingICIAP2018.

[7] A. S. Sadana, A. Prawesthi A, and A. I. Wibisono. Visual Image of Architectural Elements as The Identity of Menanga Traditional Village, Paper presented at International Conference of Hunian, Department of Architecture, Universitas Brawijaya; 2019. Available online at https://doi.org/10.2991/aer.k.200729.015.

[8] H. A. Bala. Landmarks in Urban Space as Signs. Scientific Research Pubuishing, Current Urban Studies; 2016, p. 4, 409-429.

[9] Trancik, R. Finding Lost Space: Theories of Urban Design. New York: Van Nostrand Reinhold; 1986.

[10] Asriana N, and Mega S. Karakteristik Kampung AlMunawar 13 Ulu Palembang Beserta Pendekatan Historic Urban Landscape sebagai Upaya Pelestariannya. Proceedings of Temu Ilmiah IPLBI; 2018, p. 029-035.

[11] Google Maps. Kampung Wisata Al Munawar. www.google.com/maps: 2020.

[12] M. E. P. Putra, Video Dokumenter Kampung Arab Al-Munawar 13 Ulu Palembang. Youtube.com; 2018.

[13] Dan On The Road. Colorful Kampung Al-Munawar In Palembang. www.dansontheroad.com: August 27, 2018. 
(This page is intentionally left blank) 